\title{
Rheological and Chemical Characteristics of Some Egyptian and Yemeni Wheat Verities
}

\author{
ALI M. Al-Mahturi ${ }^{1,2}$; Sharoba, A.M. ${ }^{1}$; El-Desouky, A.I. ${ }^{1}$ \\ and Mahmoud, M.H.M. ${ }^{1}$ \\ ${ }^{1}$ Food Tech. Dept., Fac. of Agric., Moshtohor, Benha Univ., Egypt. \\ ${ }^{2}$ General Corporation for Grains Development and production - Ministry of Agriculture and Irrigation - \\ Republic of Yemen. \\ Corresponding author: almodory55@gmail.com
}

\begin{abstract}
This study aimed to evaluate wheat verities of Yemeni wheat (Saba1 and Bahoath 13) and Egyptian wheat (Masr 1 and Gemmiza 11) for the ability to use in bread production. All varieties were milled and separation to $72 \%$ extraction at the same commercial condition in Egyptian mills. The chemical composition and rheological properties were measured. The results showed that the protein content was high in Masr 1 (13.93\%) and the lowest in Saba1 (12.19\%), the high content of ash in Saba1 (0.78\%) and the lowest content in Bahoath13 (0.65\%). The rheological properties measured by Farinograph, Extensograph, Mixolab and Alveograph. The results from Farinograph showed the highest stability value in Masr 1 (12.5 min) and the lowest in Bahoath 13 (2.5 min), also the Extensograph results were high in Masr 1 and the lowest in Bahoath 13. The results which obtained from Mixolab and Alveograph were the similar results with Farinograph and Extensograph. So this study recommended to increase the extension of cultivation and using of Masr 1 and Saba 1 in bakery products.
\end{abstract}

Key words: Yemeni wheat, Egyptian wheat, chemical composition, rheological properties, Mixolab, Alveograph, Farinograph, Extensograph.

\section{Introduction}

Wheat is the leading cereal grains produced in the world, used for food $(67 \%)$, feed $(20 \%)$, seed (7\%) and losing $(60 \%)$ Durum and other hard wheat contain more protein $(12-16 \%)$ than soft wheat $(8-10 \%)$ (USDA/NASS, 2001).

Egypt remains the world's largest wheat importer. Wheat imports for the 2017/18 marketing year (July/June) are estimated at 12 million tons, about the same as the previous year and about $9 \%$ above the average for the last five years. The overall cereal import requirements in the 2017/18 marketing year (July/June) are forecast at around 22.1 million tones, some 2 million tones more than in the previous year and $17 \%$ higher than the five-year average, FAO (2017).

In Yemen, owing to a variety of natural conditions, agricultural activities vary greatly depending on the location. In Central Highlands, wheat, planted in December, is currently being harvested. Total cereal production in 2016 is estimated at 480000 tons, including 220000 tons of sorghum and 150000 tons of wheat, about $11 \%$ below the previous year's harvest and $37 \%$ below the fiveyear average. Agricultural production and livelihoods were affected by the ongoing conflict as well as torrential rains which caused flash floods and landslides in July 2016, (FAO, 2017)

In Yemen, bread is consumed at higher ratios than other some countries. It is reported that the amount of daily consumption ranged from 250-320 g per capita according to the imported quality of wheat.
Yemen imports annually about $90 \%$ of its needs of wheat grains mainly for bread making and other bakery products. Milling of wheat grains took place in a local national milling plants situated in Aden (commercial capital of Rep. of Yemen) an international well known seaport as well as in another city which is considered the next seaport of Yemen (Al-Hoddidah) (Al-Mussali and Al-Gahri., 2009)

The baking industry has undergone very important changes in its productive processes. Some of the major changes have been brought about by an increasing mechanization in its processing unit operations. This fact has contributed to an increased demand for strong wheat flours, yielding doughs with high tolerance to handling and mixing, and able to remain stable during fermentation. Functional properties of flours greatly depend on the gluten proteins. The quality of gluten is dependent on diverse factors such as wheat variety and growing conditions. For this reason, the capacity of some countries to produce high-quality flours is limited. In this context, the treatment of flours with functional additives must be considered (Caballero et al. 2007).

Wheat processing like milling can result in a significant change in the nutritional value of the ultimate wheat products. The nutrients concentrated in the bran layers and germ will be removed during the traditional or conventional milling. The most affected compound during conventional milling is the crude fiber followed by the ash (minerals) and vitamins, having a detrimental effect on the nutritional value. Without the bran and germ, about $25 \%$ of the grain 
proteins are lost, along with $66 \%$ of fiber, $92 \%$ of selenium, $62 \%$ of folate, and up to $99.8 \%$ of phytochemicals, (Rosell, and Garzon, 2015).

Jalal et al. (2010) studied the chemical composition of wheat Samra Yemeni (65.90\% extraction) and they found that it contained $12.34 \%$ protein, $1.67 \%$ crude extract, $0.68 \%$ ash, $12.50 \%$ moisture and $23 \%$ gluten on wet weight.

The measurer of rheological properties of wheat flour dough is essential for the successful manufacturing of various bakery products because they determine the behavior of dough during mechanical handling, thereby affecting the quality of the finished products (Bloksma and Bushuk, 1988).

The farinograph is the machines which have been used traditionally to test the quality of doughs. These machines operate either empirically or imitatively, because the instruments were designed to show the mechanical strength of doughs under a very limited set of conditions, which usually impose high deformation forces, they often fail to describe dough flow properties. The instruments have hampered attempts to explain dough behaviour in molecular terms or to predict the action of dough improvers because they record their data in arbitrary units which cannot be used at a fundamental level to give information about the rheology of the dough system (Watanabe et al., 1992)

Mixolab is instrument developed by Chopin Technologies Company and the information related to its utilization on different aspects of wheat flour quality is quite limited. It has the capabilities to measure physical dough properties like dough strength and stability, and also to measure the pasting properties of starch on actual dough. It is used to characterise the rheological behaviour of dough subjected to a dual mixing and temperature constraint. It measures in real time the torque $(\mathrm{Nm})$ produced by mixing of the dough between the two kneading arms (Anonymous, 2005).

The aim of this work was to study chemical analysis and the rheological properties to characterize some Egyptian and Yemeni wheat varieties in order to produce the appropriate industry from the baked industry.

\section{Materials and Methods}

\section{Raw Materials:}

The materials used in this investigation and their sources were:

\section{a. Egyptian Wheat:}

Two different varieties of wheat Masr 1 and Gemmiza 11 season 2017 were obtained from the Agricultural Research Center, Giza, Egypt.

\section{b. Yemeni Wheat}

Two different varieties of wheat Saba 1 and Bahoath 13 season 2017 were obtained from the Agricultural Research Center in Sana'a Yemen.
Methods:

\section{Preparation of flour:}

All wheat varieties were milled and separated to (72\% extraction rate) in Egyptian Baking Technology Center using Brabender mill type.

2. physicochemical characters:

Hectoliter weight and thousand kernel weight of different wheat varieties were determined using stander procedures according to A.A.C.C. (2000).

\section{Chemical analysis:}

Moisture, crude protein, ether extract and ash content were determined according to the methods of A.O.A.C. (2006). Total carbohydrates was calculated by differences.

\section{Gluten characteristics:}

Gluten characteristics which include wet gluten, dry gluten, water-binding capacity and gluten index were estimated according to A.A.C.C. (2000).

\section{Rheological properties of wheat flour: a. Farinograph and Extensograph test:}

Farinograph and Extensograph tests were carried out to determine the water absorption, dough development time, dough stability and dough weakening and elasticity, extensibilty, proportion number and energy of wheat flour ( $72 \%$ extraction rate) according to the method described in A.A.C.C. (2000).

\section{b. Mixolab:}

Dough rheological behavior was studied using Mixolab which simultaneously determines dough characteristics during the process of mixing at constant temperature, as well as during the period of constant heating and cooling Ozturk et al. (2008).

Mixolab analysis was carried out at the water absorption level determined by the Consistograph following the A.A.C.C. (2000).

\section{c. Alveograph}

The Alveograph characteristics of wheat flour were determined in a Chopin NG Alveograph using A.A.C.C (2000). The Alveograph parameters were automatically recorded by Chopin Alveolink-NG software, including the maximum overpressure or tenacity $(\mathrm{P})$ needed to blow the dough bubble, the abscissa at rupture (L) measuring dough extensibility, the index of swelling $(\mathrm{G})$ (measured as the square root of the volume of air necessary to inflate the dough bubble until it ruptures), the deformation energy of dough (W) representing the energy necessary to inflate the dough bubble to the point of rupture, the deformation curve (P/L) and the elasticity index (Ie).

\section{d. Falling number (No.) test:}

Falling No. was determined according to the method described in A.A.C.C. (2000).

\section{Statistical analysis:}

The statistical analysis was carried out using one-way ANOVA using SPSS, ver. 22 (IBM Corp. Released 2013). Data were treated as a complete 
randomization design according to Steel et al. (1997). Multiple comparisons were carried out applying Duncun test the significance level was set at $<0.05$.

\section{Results and Discussion}

\section{Physical characterization:}

Hectoliter one of the most parameters, which are used globally to the distinction between the wheat grain properties, as well it affected by many factors such as genotype, environment and fertilizer. The physical properties of the wheat kernel as described in Table (1). The optioned data indicated that there was a significant difference $(\mathrm{P}<0.05)$ between each parameter. In the same time Duncun test divided the 4 studied samples into 2 subgroups. $1^{\text {st }}$ group included Gommiza 11 and Masr 1 samples with highest hectoliter value. The $2^{\text {nd }}$ subgroup with included Saba 1 and Bahoath 13 samples. The highest value of hectoliter was detected with Masr 1 at 86.19 $\mathrm{kg} /$ hectoliter, while the lowest value was detected with Bahoath 13 at $83.97 \mathrm{~kg} /$ hectoliter. These results are in agreement those obtained by (Prabhasankar and Rao, 2001) they found that the kernel weight (hectoliter) for most bread wheat varieties in worldwide ranged from 71 to $85 \mathrm{~kg} / \mathrm{h}$.

Table 1. Physico characters of some Yemeni and Egyptian wheat varieties.

\begin{tabular}{lcccc}
\hline \multirow{2}{*}{ Parameter } & \multicolumn{2}{c}{ Yemeni varieties } & \multicolumn{2}{c}{ Egyptian varieties } \\
\cline { 2 - 5 } & Saba 1 & Bahoath 13 & Gemmiza 11 & Masr 1 \\
\hline Hectoliter (kg/hectoliter) & $84.73 \pm 0.62^{\mathrm{b}}$ & $83.97 \pm 0.57^{\mathrm{b}}$ & $85.97 \pm 0.43^{\mathrm{a}}$ & $86.19 \pm 0.57^{\mathrm{a}}$ \\
Thousand kernel weight $(\mathbf{g})$ & $37.45 \pm 0.55^{\mathrm{b}}$ & $36.51 \pm 0.50^{\mathrm{b}}$ & $41.05 \pm 0.55^{\mathrm{a}}$ & $40.75 \pm 0.50^{\mathrm{a}}$ \\
\hline
\end{tabular}

a, b \& c: There is no significant difference $(\mathrm{P}>0.05)$ between any two means for the same attribute, within the same row have the same superscript letter.

Thousand kernel weight (TKW) is one of the most important parameter are used to indicate the grain characters and factors affected of the wheat grain parameters such as genotype and environment, etc. The results in Table (1), it could be indicated that the TKW ranged from $41.05 \mathrm{~g}$ with Gemmiza 11 to 36.51 $\mathrm{g}$ with Bahoath 13. In the same time Duncun test divided the 4 studied samples into 2 subgroups. $1^{\text {st }}$ group included Gommiza 11 and Masr 1 samples with thousand kernel weight. The $2^{\text {nd }}$ subgroup with included Saba 1 and Bahoath 13 samples. These results are in agreement with Wang et al., (2012). The many of the studies are shown to presence the relation between the TKW and protein content and then quality of wheat products, which depend mainly on genetic factor and environmental condition (Ramya $\boldsymbol{e t}$ al., 2010).

\section{Chemical composition:}

The chemical compositions of Yemeni and Egyptian wheat flour are shown in Table (2). The results showed that there are a significant difference $(\mathrm{P}>0.05)$ between any varieties. The moisture ranged from 11.75 to $12.47 \%$, the highest percentage was found in Masr 1 (72\% ext.) and the lowest value was found in Gemmiza 11 (72\% ext.). The obtained data in Table (2) showed that a significant decrease in moisture content between Gommaiza 11 sample and other samples. While there is non-significant difference between Masr 1, Saba 1 and Bahoath 13 samples. These results are in agreement with ElPorai et al., (2013) they found the moisture content $12.8 \%$ in Gommiza 11 wheat flour.

Table 2. Chemical composition of some Yemeni and Egyptian wheat flour (72\% ext.)

\begin{tabular}{|c|c|c|c|c|}
\hline \multirow{2}{*}{ Components (\%) } & \multicolumn{2}{|c|}{ Yemeni varieties } & \multicolumn{2}{|c|}{ Egyptian varieties } \\
\hline & Saba 1 & Bahoath 13 & Gemmiza 11 & Masr 1 \\
\hline Moisture & $1242^{ \pm} 0.07^{\mathrm{a}}$ & $1227 \pm 0.18^{a b}$ & $11.75 \pm 0.20^{b}$ & $12.47 \pm 0.10^{\mathrm{a}}$ \\
\hline Crude protein* & $12.19 \pm 0.95^{c}$ & $1248 \pm 0.35^{c}$ & $13.17 \pm 0.23^{b}$ & $13.93 \pm 0.17^{\mathrm{a}}$ \\
\hline Ether extract* & $1.12+0.17^{b c}$ & $1.32+0.17^{a}$ & $1.09 \pm 0.12^{c}$ & $1.18 \pm 0.12^{b}$ \\
\hline $\operatorname{Ash}^{*}$ & $0.78+0.31^{\mathrm{a}}$ & $0.65 \pm 0.10^{c}$ & $0.74 \pm 0.12^{a b}$ & $0.69 \pm 0.10^{b c}$ \\
\hline Total carbohydrate* & $85.91 \pm 0.85^{a}$ & $85.55 \pm 0.85^{\mathrm{ab}}$ & $85.01 \pm 0.89^{b}$ & $84.21 \pm 1.26^{c}$ \\
\hline
\end{tabular}

*: (On dry weight basis)

$\mathrm{a}, \mathrm{b} \& \mathrm{c}$ : There is no significant difference $(\mathrm{P}>0.05)$ between any two means for the same attribute, within the same row have the same superscript letter.

A higher level of protein content was found in Masr $113.93 \%$ (72\% ext.), while, the lowest level of protein content was found in Saba $112.19 \%$. The results indicated that there is a significant differense in crude varieties are considered to be of medium wheat varieties. There are many reasons that affect the protein content of wheat variety such as environmental conditions, agriculture protein content between Maser 1 sample and other samples. But, there is non significant difference between Saba 1 and Bahouth 13 samples. These operations, and fertilizing (Sip et al., 2013). Also, ether extract is one of the most component that changing depending on the varieties and extraction rate. Results showed that there are 
significant differences between all varietes. Bahoath 13 achieved a high content for ether extract $1.32 \%$, but the Gemmiza 11 was a lower value $1.09 \%$. These results are consistent with (Gray and Bemiller, 2003). On the other hand, ash content showed that there are significant differences between all varieties. A higher level of ash content was observed in Saba 1 $0.78 \%$. The results of total carbohydrate content indicated that there is a significant difference $(\mathrm{P}>0.05)$ between the different varieties. The high content was found in Saba 1 (85.91\%), while the lowest content was found in Masr 1 (84.21\%), (El-Porai et al., 2013).

\section{Phy-siochemical properties}

The gluten and falling number of Yemeni and Egyptian wheat flour samples are shown in Table (3). The results showed that the Bahoath 13, Saba 1, Gemmiza 11 and Masr 1 wheat flour contains 38.23, $34.60,29.67$ and $36.96 \%$ wet gluten and 12.13, 11.20, 10.30 and $11.46 \%$ dry gluten, respectively. Also, results showed that the index gluten was 14.56, 10.20, 58.03 and $97.40 \%$, respectively. But, the falling number was 317, 419, 3470 and $320(\mathrm{Sec})$ falling No, for Bahoath 13, Saba 1, Gemmiza 11 and Masr 1 wheat flour, respectively.

Table 3. Physiochemical properties of Egyptian and Yemeni wheat flour (72\%ext.):

\begin{tabular}{lcc|cc}
\hline \multicolumn{1}{c}{ Components } & \multicolumn{4}{c}{ Varieties } \\
\cline { 2 - 5 } & Saba 1 & Bahoath 13 & Gemmiza 11 & Masr 1 \\
\hline Wet gluten content (\%) & $34.60 \pm 0.26^{\mathrm{c}}$ & $38.23 \pm 0.38^{\mathrm{a}}$ & $29.67 \pm 0.29^{\mathrm{d}}$ & $36.96 \pm 0.12^{\mathrm{b}}$ \\
Dry gluten content (\%) & $11.20 \pm 0.15^{\mathrm{b}}$ & $12.13 \pm 0.17^{\mathrm{a}}$ & $10.30 \pm 0.05^{\mathrm{c}}$ & $11.46 \pm 0.14^{\mathrm{b}}$ \\
Gluten Index & $10.20 \pm 0.40^{\mathrm{d}}$ & $14.56 \pm 0.29^{\mathrm{c}}$ & $58.03 \pm 0.35^{\mathrm{b}}$ & $97.40 \pm 0.32^{\mathrm{a}}$ \\
Falling. No (Sec) & $419 \pm 2.33^{\mathrm{a}}$ & $317 \pm 4.04^{\mathrm{c}}$ & $347 \pm 1.52^{\mathrm{b}}$ & $320 \pm 2.88^{\mathrm{c}}$ \\
\hline
\end{tabular}

$\mathrm{a}, \mathrm{b} \& \mathrm{c}$ : There is no significant difference $(\mathrm{P}>0.05)$ between any two means for the same attribute, within the same row have the same superscript letter.

These results are nearly agreement with those reported by Paucean et al. (2016) and Liu et al. (2017). Gluten is a measure of gluten strength and gas retention. The gluten index was highest in Masr 1 and Gemmiza 11, and it is very low in Bahoath 13 and Saba 1. The falling number depends on some factors such as milling methods. storage environment and shelf life. The falling number was higher in wheat Saba 1 than other Liu et al., (2017).

\section{Farinograph properties}

Farinograph was used to study the hydration and mixing characteristics of that resultant dough by four types of Yemeni and Egyptian wheat flour consists of Bahoath 13, Saba 1, Gemmiza 11 and Masr 1. As shown in Table (4) and Fig. (1), the percentage of water absorption in Masr 1, Gemmiza 11, Bahoath 13 and Saba 1 was $76.0 \%, 72.0,71.5$ and $67.5 \%$, respectively. While the stability time in Masr 112.5 (min) was higher than that in Gemmiza 11, Saba 1 and Bahoath 13 which was 5.5, 3.5 and 2.5 ( $\mathrm{min}$ ), respectively. These results may be attributed to the finding that Masr 1 had the highest values of protein which caused an increase in water absorption percentage, dough development and dough stability times compared to the other tested cultivars. These results are in agreement with these reported by Ibrahim et al., (2011) and Paucean et al., (2016).

Table 4. Farinograph properties of some Yemeni and Egyptian wheat flours (72\% ext.).

\begin{tabular}{lccccc}
\hline verities & $\begin{array}{c}\text { Water } \\
\text { Absorption } \%\end{array}$ & $\begin{array}{c}\text { Arrival } \\
\text { time } \\
(\text { min) }\end{array}$ & $\begin{array}{c}\text { Dough } \\
\text { Development } \\
(\text { min })\end{array}$ & $\begin{array}{c}\text { Stability } \\
\text { time (min) }\end{array}$ & $\begin{array}{c}\text { Degree of } \\
\text { softening (B.U) }\end{array}$ \\
\hline Bahoath 13 & 71.5 & 1.5 & 2.0 & 2.5 & 140 \\
Saba 1 & 67.5 & 1.0 & 1.5 & 3.5 & 110 \\
Gemmiza 11 & 72.0 & 2.5 & 4.5 & 5.5 & 90 \\
Masr 1 & 76.5 & 1.0 & 1.5 & 12.5 & 20 \\
\hline
\end{tabular}

Bahoath 13 wheat flour




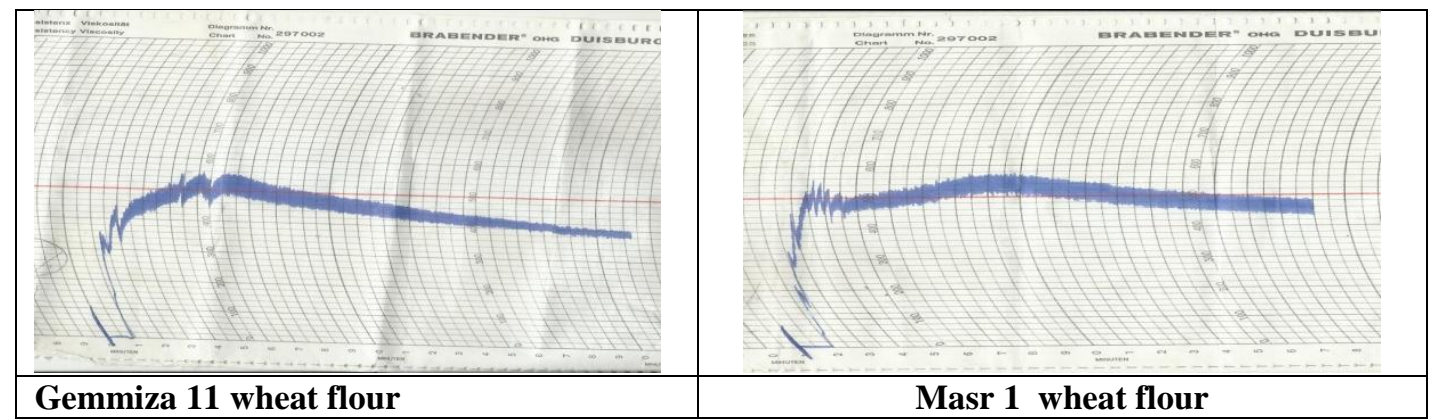

Fig. (XII): Farinograph diagrams of some Yemeni and Egyptian wheat flours.

\section{Extensograph properties}

The practical results obtained from the Extensograph test are always based on the results of the Farinograph. It is possible to obtain elasticity, extensibility, proportional number and energy. Results in Table (5) and Fig. (2), showed that, the elasticity in Masr 1 is higher than the Gemmiza 11 and Saba 1 and Bahoath 13. The obtained results were 670, 390,
340 and 260 (B.U) for Masr 1, Gemmiza 11, Saba 1and Bahoath 13 respectively. Extensibility was 135, 85, 75 and $75 \mathrm{~mm}$ for Bahoath 13, Masr 1, Saba 1 and Gemmiza 11 flour samples. The highest proportional number was noted for Masr 1 indicating a balance of protein characteristic and dough quality in this cultivar. Similar results were obtained by Seleiman $\boldsymbol{e t}$ al. (2010).

Table 5. Extensograph properties of some Yemeni and Egyptian wheat flours (72\% ext.):

\begin{tabular}{ccccc}
\hline Verities & Elasticity (B.U) & $\begin{array}{c}\text { Extensibility } \\
(\mathbf{m m})\end{array}$ & $\begin{array}{c}\text { Proportional } \\
\text { number }\end{array}$ & Energy $\left(\mathbf{c m}^{\mathbf{2}}\right)$ \\
\hline Bahoath 13 & 260 & 135 & 1.92 & 35 \\
Saba 1 & 340 & 75 & 4.53 & 25 \\
Gemmiza 11 & 390 & 75 & 5.2 & 30 \\
Masr 1 & 670 & 85 & 7.88 & 50 \\
\hline
\end{tabular}

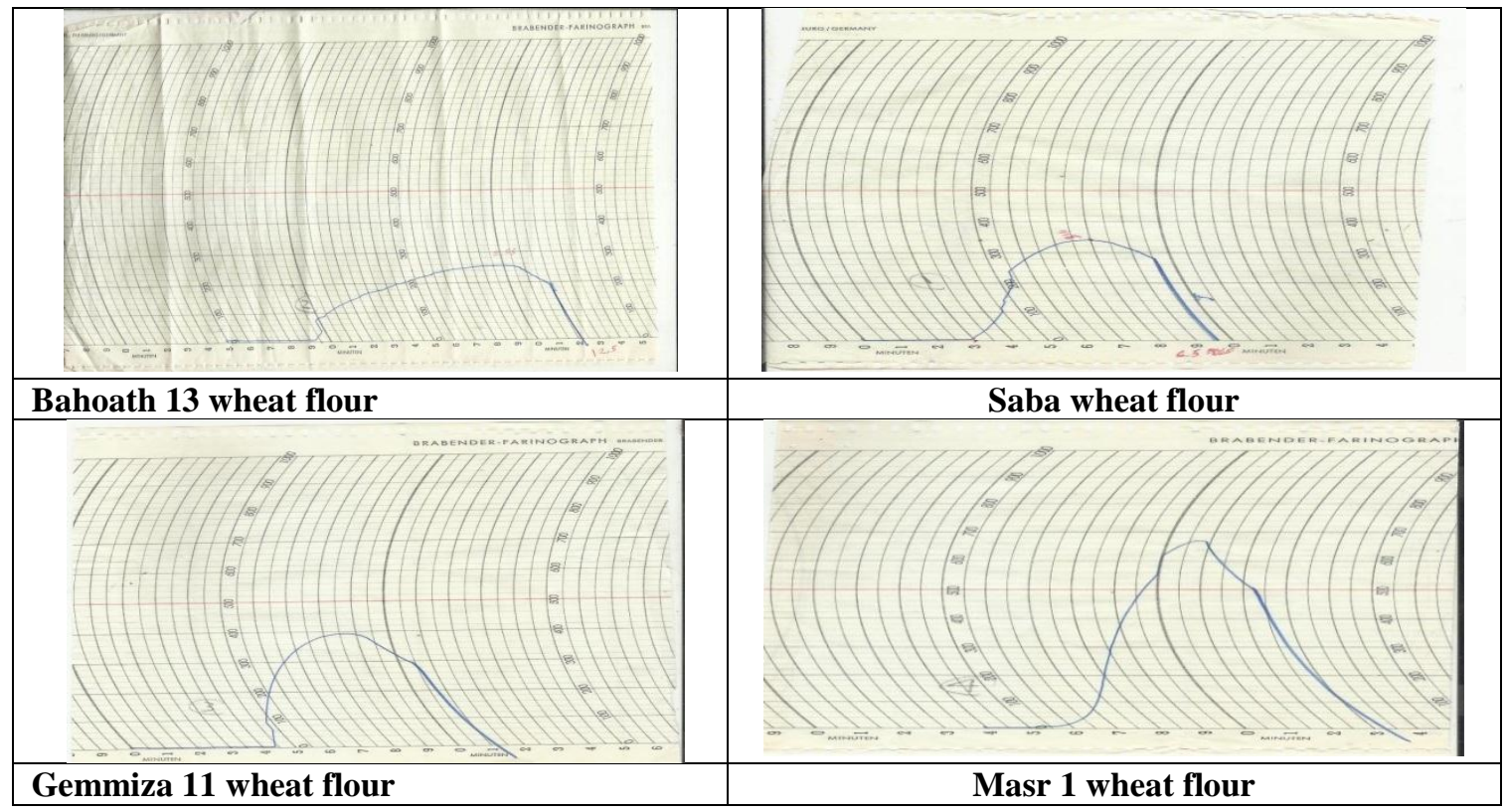

Fig. (XIII): Extensograph diagrams of some Yemeni and Egyptian wheat flours.

\section{Mixolab:}

In most countries of the world, it relied only on the known and old devices in measuring the rheological properties, namely the farinograph and Extensograph systems in the judgment of the rheological properties of flour used in the manufacture of baked goods A major development in many countries is now in the use of modern devices to measure the rheological properties of Alveograph and Mixolab Therefore, in this study used the old devices in the previous part was also measuring with modern devices with the same samples under the study in order to set limits for the results of the two Alveograph and Mixolab It is 
possible for bakers and bakeries to rely on them as guides to guide the product to the optimum industry.

Recently, Mixolab is advanced technique for measuring the rheological properties of dough, so, in the part we focus on utilized of Mixolab and compared with old method for rheological properties determined. Results shown in Table (6). However, Masr 1 wheat flour required considerably larger amount of water (7 WA) to achieve a torque of 1.06 $\mathrm{Nm}$, Higher absorption, lower dough development time and higher mechanical weakening in comparison to wheat flour were also observed for Bahoath 13 wheat flour. On heating, aggregation and denaturation of the proteins occurs, which result in a decrease in dough consistency ( $\mathrm{C} 2$ value). The increase in viscosity and thus in the torque is the result of the starch granules swelling due to the water uptake and amylose chains leaching into the aqueous intergranular phase. Hadnađev et al. (2011). The third phase (C3), which is called starch gluten at this stage and the product during heating where a sample Bahoath be higher than 13 samples Gemmize 11 and then followed by a sample of Masr 1 and Saba 1 from 2.12 to $1.45 \mathrm{Nm}$. According to Abd El-Rahman (2016) and Khaleel (2017).

Table 6. Mixolab characteristics of some Yemeni and Egyptian wheat flours:

\begin{tabular}{lcccc}
\hline \multirow{2}{*}{ Characteristics } & \multicolumn{4}{c}{ Varieties } \\
\cline { 2 - 5 } & Bahoath 13 & Saba 1 & Gemmiza 11 & Masr 1 \\
\hline Stability (min) & 3.22 & 6.30 & 8.95 & 9.60 \\
Water Absorption & 1 & 2 & 2 & 7 \\
Mixing & 1 & 2 & 1 & 6 \\
Gluten+ & 8 & 5 & 6 & 5 \\
Viscosity & 4 & 2 & 4 & 3 \\
Amylase & 3 & 2 & 8 & 7 \\
Retro gradation & 5 & 3 & 8 & 1.06 \\
C1 (Nm) & 1.10 & 1.13 & 1.06 & 0.49 \\
C2 (Nm) & 0.84 & 0.47 & 0.42 & 1.67 \\
C3 (Nm) & 2.12 & 1.45 & 1.69 & 1.60 \\
C4 (Nm) & 1.76 & 1.04 & 2.03 & 2.61 \\
C5 (Nm) & 3.93 & 1.52 & 3.08 & \\
\hline
\end{tabular}

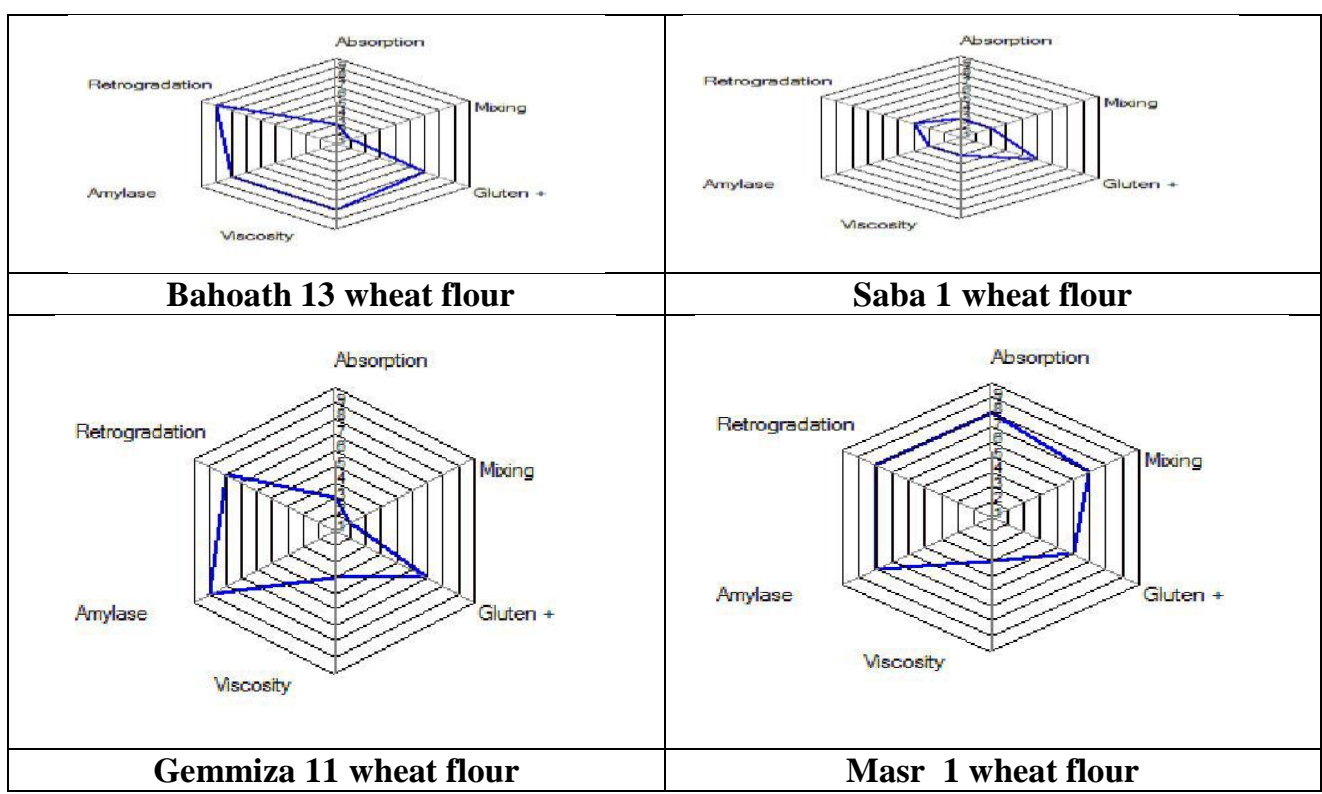

Fig. (XIV): Mixolab diagrams of some Yemeni and Egyptian wheat flour (72\%).

\section{Alveograph:}

Flexibility or elasticity (L) was increased in a Bahoath 13 sample where elasticity or elasticity (L) was in a mass sample of $52 \mathrm{~mm}$, while L for Saba 1 sample was $45 \mathrm{~mm}$. The results in Table (7) showed that, the value of resistance $(\mathrm{P})$ was $177,127,74$ and $74 \mathrm{~mm}$ in Masr 1, Gemmiza 11, Bahoath 13 and Saba
1 respectively, according to Hassan (2010) and Barros et al. (2018). Flexibility or elasticity (L) was $52,45,43$ and $35 \mathrm{~mm}$, respectively, in the Bahoath 13, Saba 1, Gemmiza 11 and Masr 1, respectively , according to Abd El-Rahman (2016) and Khaleel (2017). 
Table 7. Alveograph characteristics of some Yemeni and Egyptian wheat flours.

\begin{tabular}{lccc}
\hline verities & P $(\mathbf{m m})$ & L $(\mathbf{m m})$ & (P/L Ratio) \\
\hline Bahoath 13 & 74 & 52 & 1.42 \\
Saba 1 & 74 & 45 & 1.60 \\
Gemmiz 11 & 127 & 43 & 2.9 \\
Masr 1 & 177 & 35 & 5.06 \\
\hline
\end{tabular}

References

A.A.C.C. (2000). American Association of Cereal Chemists. Approved method of the A.A.C.C. $10^{\text {th }}$ ed. Association of Cereal Chemists, st., paul, Minnesota, USA.

Anonymous (2005). Mixolab user's manual. Tripette $\&$ Renaud Chopin, France

A.O.A.C. (2006). Official Methods of Analysis. $18^{\text {th }}$ Edition, Association of Official Analytical Chemists, Gaithersburgs, MD., USA.

Abd El-Rahman, M.G. (2016). Using of some enzymes to improve quality of some bakery products. M.Sc. Thesis, Agric. Sci., Agric. Fac., Moshtohor, Benha University, Egypt.

Al-Mussali, M. S., and Al-Gahri, M. A. (2009). Nutritive value of commonly consumed bread in Yemen. Journal of Chemistry, 6(2), 437-444.

Barros, J. H.; Telis, V. R.; Taboga, S., and Franco, C. M. (2018). Resistant starch: effect on rheology, quality, and staling rate of white wheat bread. Journal of food science and technology, 55(11): 4578-4588.

Bloksma AH, Bushuk W (1988). Rheology and chemistry of doughs. In: Pomeranz Y (ed) Wheat: chemistry and technology, 3rd edn, vol II. AACC, St Paul, pp 131-218.

Caballero, P.A.; Gomez, M. and Rosell, C.M. (2007). Improvement of dough rheology, bread quality and bread shelf-life by enzymes combination. Journal of Food Engineering, 81(1): 42-53.

El-Porai, E.; Salama, A.; Sharaf, A.; Hegazy, A. and Gadallah, M. (2013). Effect of different milling processes on Egyptian wheat flour properties and pan bread quality. Annals of Agricultural Sciences, 58(1): 51-59.

FAO(2017): http://www.fao.org/giews/countrybrief/c ountry.jsp?code $=$ YEM

FAO(2017): http://www.fao.org/giews/countrybrief/c ountry.jsp?code $=E G Y$

Gray, J. and Bemiller, J. (2003). Bread staling: molecular basis and control. Comprehensive Reviews in Food Science and Food Safety, 2(1): $1-21$.

Hadnađev, T. D.; Torbica, A. and Hadnađev, M. (2011). Rheological properties of wheat flour substitutes/alternative crops assessed by Mixolab. Procedia Food Science, 1: 328-334.

Hassan, A.A. (2010). Improvement of the quality of some food diughs by using some food additives. Ph.D. Thesis, Agric. Sci. Agric. Fac., Minufiya University, Egypt.
Ibrahim, M. E.; Abdel-Aal, S. M.; Hussein, A. S. and Gafar, N. A. (2011). Technological, rheological and yield differences among Egyptian wheat varieties. Journal of the Science of Food and Agriculture, 91(5), 831-840.

Jalal, A. F.; Mutair, S. S. and Mohamed, A. A. (2010). Comparison of Physical, Chemical and Rheological Baking properties of some domestic and imported wheat Categories. Ass. Univ. Bull. Environ. Res.13 (2): 37-51.

Khaleel, M.L. (2017). Studies on Some Iraqi and Egyptian Bakery Products. M.Sc. Thesis, Agric. Sci. Agric. Fac., Moshtohor, Benha University, Egypt.

Liu, T.; Hou, G.G.; Cardin, M.; Marquart, L. and Dubat, A. (2017). Quality attributes of wholewheat flour tortillas with sprouted whole-wheat flour substitution. LWT-Food Science and Technology, 77: 1-7.

Ozturk, S.; Kahraman, K., Tiftik, B. and Koksel, H. (2008). Predicting the cookie quality of flours by using Mixolab®. European Food Research and Technology, 227(5), 1549-1554.

Paucean, A.; Man, S. and Socaci, S.A. (2016). Wheat germ bread quality and dough rheology as influenced by added enzymes and ascorbic acid. Studia Universitatis Babes-Bolyai, Chemia, 61(2): 103-118.

Prabhasankar, P. and Rao, P.H. (2001). Effect of different milling methods on chemical composition of whole wheat flour. European Food Research and Technology, 213(6): 465-469.

Ramya, P.; Chaubal, A.; Kulkarni, K.; Gupta, L.; Kadoo, N.; Dhaliwal, H.S.; Chhuneja, P.; Lagu, M. and Gupt, V. (2010). QTL mapping of 1000kernel weight, kernel length, and kernel width in bread wheat (Triticum aestivum L.). Journal of Applied Genetics, 51(4): 421-429.

Rosell, C.M. and Garzon, R. (2015). Chemical Composition of Bakery Products. Handbook of Food Chemistry, 1-28.

Seleiman, M. F.; Abdel-Aal, S. M.; Ibrahim, M. E. and Monneveux, P. (2010). Variation of yield, milling, technological and rheological characteristics in some Egyptian bread wheat (Triticum aestivum L.) cultivars. Emirates Journal of Food and Agriculture, 84-90.

Sip, V.; Vavera, R.; Chrpova, J.; Kusa, H. and Ruzek, P. (2013). Winter wheat yield and quality related to tillage practice, input level and environmental conditions. Soil and Tillage Research, 132: 77-85. 
Steel, R.; Torrie, J. and Dickey, D. (1997): Principles and procedures of Statistics: A Biometrical Approach, $3^{\text {rd }}$ ed., McGraw-Hill, New York, NY.

USDA/NASS, (2001). Agricultural Statistics. U.S. Department of Agriculture, National Agricultural Statistics Service. U.S. Government Printing Office, Washington, DC,USA.
Wang, L.; Ge, H.; Hao, C.; Dong, Y. and Zhang, X. (2012). Identifying loci influencing 1,000-kernel weight in wheat by microsatellite screening for evidence of selection during breeding. PLoS One, 7(2): e29432.

Watanabe, E.; Bell, A. E. and Brockway, B. E. (1992). Rheological studies on wheat flour dough. I. Empirical and fundamental methods. Food Control, 3(2), 97-101.

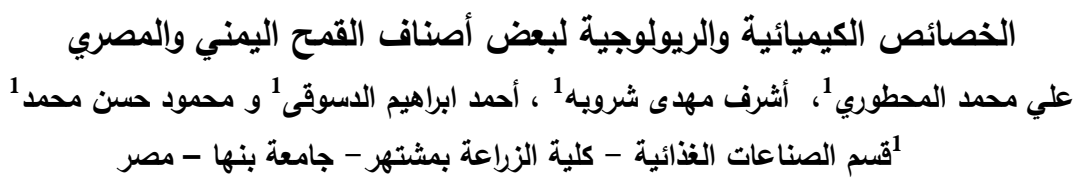

تم في هذه الدراسة أستخدام أربعة أصناف قمح أثثان منها من اليمن (سبا ا - بحوث س با) وأثثان من مصر (مصر | - جميزة (1) وهي

من الاصناف متوسطة الصلابة الجديدة في الاسواق اليمنية والمصرية لدراسة مدى صلاحيتها لصناعة الخبز ومنتجات المخابز ـ تم إجراء عملية

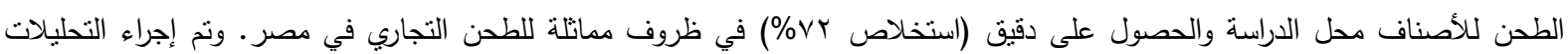
الكيميائية حيث تم تقدير نسبة الرطوبة ،البروتين ،الرماد ،الدهن وحساب نسبة الكربوهيدرات الكلية وكانت نسبة البروتين في كل من صنف مصر إنى

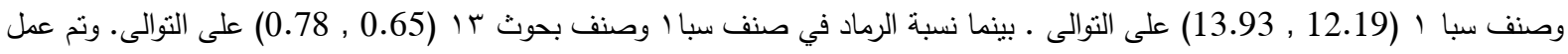
جميع الأختبارات الريولوجية بجهازى الفارينوجراف والأكستتسوجراف وكذلك بجهازى المكسولاب والألفيوجراف وأوضحت النتائج بالنسبة لجهاز

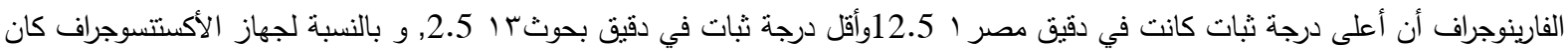

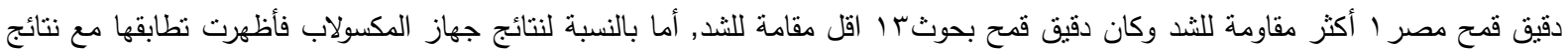
الفارينوجراف وكذللك أظهرت نتائج جهاز الألفيوجراف نطابقا مع نتائج جهاز الأكستنسوجراف المتحصل عليها. ومن النتائج السابقة يتضح أن الأصناف المصرية مناسبة جدا لصناعة الخبز البلدي والأصناف اليمنية تصلح لصناعة البسكويت والكيلك. ولذلك توصى الدراسة النوسع في زراعتها وإستخدام كل من الصنف المصري مصر ا واليمني سبا الفي تصنيع منتجات المخابز.

الكلمات الدالة: القمح اليمنى ـ القمح المصرى ـ التركيب الكيماوى ـ الخصائص الريولوجية ـ المكسولاب ـ الألفيوجر اف ـ الفارينوجر اف ـ الإكستنسوجر اف الفن. 